\title{
62. DATA REPORT: STUDIES INTO THE PALEONTOLOGY OF THE CRETACEOUS OF THE INDIAN OCEAN BASIN 1
}

\author{
Patrick G. Quilty²
}

\section{INTRODUCTION}

The Indian Ocean covers approximately $73.5 \times 10^{6} \mathrm{~km}^{3}$ from $25^{\circ} \mathrm{N}$ to $67^{\circ} \mathrm{S}$ and from $20^{\circ}$ to $120^{\circ} \mathrm{E}$. Several legs of the Deep Sea Drilling Project (DSDP) and the Ocean Drilling Program (ODP) have operated in its waters, many penetrating the Cretaceous (Table 1). Most of the scientific drill sites are DSDP related and thus pre-dated modern biostratigraphic conventions. Foraminifers and calcareous nannoplankton were by far the dominant fossil groups studied in the earlier work, supplemented occasionally by studies of other fossil groups. The results of the Ocean Drilling Project phase are yet too young to be fully integrated but have been based on a broader range of techniques and fossil groups.

During most of the Cretaceous, the proto-Indian Ocean basin lay in middle to high latitudes. Thus, it is unrealistic to expect successful routine application of low-latitude zonations.

No planktonic foraminifer zonal scheme has been developed for the Indian Ocean basin for several reasons. There are no sections with complete or even significant partial sections to allow development of such a zonation. Carbonate compensation depth (CCD) effects have been marked in most sections, and significant intervals are devoid of planktonic foraminifers. The Indian Ocean now covers a great latitudinal range from tropics to polar regions and, at first glance, no scheme can be expected to be applicable over that entire range. In the Cretaceous the area was much smaller, though expanding progressively, and the paleolatitude range was quite small.

Calcareous nannoplankton have proved valuable in dating Indian Ocean Cretaceous sediments and have, perhaps in contrast with the foraminifers, been consistently a more reliable means of applying zonal schemes developed elsewhere.

For the Albian-Aptian, zonations based on well-known benthic foraminifer lineages (Scheibnerova, 1974) have been useful when nothing else was available or effective.

Palynology has been used little, but where used, has proved excellent. It has the added value of providing valuable information on nearby terrestrial vegetation as the fossils were resistant to dissolution.

Normally, when different fossil groups have been applied to a section, the results have been compatible or compatible to an acceptable degree. There are a few instances where incompatibility is noteworthy, and Site 263 is a classic example, as even two calcareous nannoplankton studies show irreconcilable differences here. All groups gave different results, but one benthic foraminifer analysis agreed with one calcareous nannoplankton study.

\footnotetext{
${ }^{1}$ Wise, S. W., Jr., Schlich, R., et al., 1992. Proc. ODP, Sci. Results, 120: College Station, TX (Ocean Drilling Program).

2 Australian Antarctic Division, Channel Highway, Kingston, Tasmania, Australia 7050 .
}

\section{Evolution of the Indian Ocean during the Cretaceous}

This is not an exhaustive review of the Indian Ocean, but it is presented because the environment changed with time and was important in biostratigraphy.

At the beginning of the Cretaceous the Indian Ocean did not exist, and the presently surrounding continents were united as part of Gondwana, with the ocean of Tethys to its north. The dismemberment of Gondwana, insofar as it affects the Indian Ocean, began in the Late Jurassic (Larson, 1975) with the northwesterly drift of a fragment from northwestern Australia to produce a new ocean floor, now the Argo Abyssal Plain.

Greater India began its northward journey in the middle Neocomian (Johnson et al., 1976), and the generation of seafloor by this movement can be said to be the beginning of the proto-Indian Ocean (Quilty, 1984).

The evolution of the Indian Ocean from that time on has been the subject of many analyses, including those of Veevers (1984) and Royer and Sandwell (1989). The evolution of the shape of the Indian Ocean is known and for seafloor of any given age, paleodepth can be calculated readily (Veevers, 1977). With these constraints, the main features to be documented then are variations in temperature with time, variations in CCD and circulation patterns, and variations in sediment distribution caused by the above oceanographic factors, by changes in meteorological patterns (e.g., wind), and by onshore events (e.g., desertification of Australia and glaciation of Antarctica).

Throughout its history, subduction has not been a factor of importance along the western, southern, eastern, or western part of the northern margins of the basin. However, it has been a continuing factor along the eastern part of the northern margin. Along this subduction complex, much of the early ocean history has been irretrievably lost.

\section{Features of the Indian Ocean}

The Indian Ocean floor has a complex array of features (Schlich, 1982), some of which are unique to it and others for which it provides the best examples. For the unique features, note the "tramtracks of India": Ninetyeast Ridge and the Chagos-Laccadive Ridge. One of the best developed features, Kerguelen Plateau, is without peer as a submarine plateau, but it is also part of an example of paired submarine plateaus separated by a spreading center because of its initial continuity with Broken Ridge.

The Indian Ocean has many islands and seamounts, but few are well enough known yet to be cited as examples of linear volcanic island seamount chains so typical of the Pacific Ocean basin (e.g., McDougall and Duncan, 1980). All the above physical features have had an effect, both during their evolution and once formed, on circulation patterns, patterns of sediment distribution, and erosion. Some events in the history of the Indian Ocean basin had effects that were essentially restricted to it, but others, such as the development of the circumpolar current, had global significance. 
Table 1. DSDP and ODP cruises in the Indian Ocean that penetrated Cretaceous sections.

\begin{tabular}{|c|c|c|}
\hline Leg & Ports of call & Date \\
\hline \multicolumn{3}{|l|}{ DSDP } \\
\hline 22 & Darwin to Colombo & January-March 1972 \\
\hline 23 & Colombo to Djibouti & March-May 1972 \\
\hline 24 & Djibouti to Port Louis & May-June 1972 \\
\hline 25 & Port Louis to Durban & June-August 1972 \\
\hline 26 & Durban to Fremantle & September-October 1972 \\
\hline 27 & Fremantle to Fremantle & November-December 1972 \\
\hline 28 & Fremantle to Wellington & December 1972-February 1973 \\
\hline \multicolumn{3}{|l|}{ ODP } \\
\hline 115 & Port Louis to Colombo & May-June 1987 \\
\hline 116 & Colombo to Colombo & July-August 1987 \\
\hline 117 & Colombo to Port Louis & August-October 1987 \\
\hline 118 & Port Louis to Port Louis & October-December 1987 \\
\hline 119 & Port Louis to Fremantle & December 1987-February 1988 \\
\hline 120 & Fremantle to Fremantle & February-May 1988 \\
\hline 121 & Fremantle to Singapore & May-July 1988 \\
\hline 122 & Singapore to Singapore & June-August 1988 \\
\hline 123 & Singapore to Singapore & September-November 1988 \\
\hline
\end{tabular}

Note: DSDP $=$ Deep Sea Drilling Project and ODP $=$ Ocean Drilling Program.

Scientific ocean drilling in the region is restricted to Legs 22-28 (Deep Sea Drilling Project) and Legs 115-123 (Ocean Drilling Program). In all of these efforts, Cretaceous sequences were drilled in only 22 legs (up to and including Leg 120), and even these legs penetrated either discontinuous sequences or sequences in which only a short time interval is represented.

Little is known of Indian Ocean Cretaceous foraminifers and calcareous nannofossils other than the sporadic records represented in DSDP Legs $22-28$ and in such even more serendipitous records, as described by Burckle et al. (1967), Quilty (1973, 1979), and Bassias et al. (1987).

The section in Site 747 holes provides a, so far,. unique opportunity to describe the high-latitude Campanian-Maestrichtian forms of the Southern Hemisphere, to relate them to paleoenvironmental parameters, and to provide samples of sufficient quality to make oxygen isotope studies worthwhile. From all these approaches, there should come significant paleoceanographic synthesis.

\section{RESULTS}

\section{Previous Results}

In compiling the following data, I have accepted the age assignments used in the original papers and applied the zonal schemes employed there. When the Indian Ocean sections were drilled by the Deep Sea Drilling Project, a radiolarian zonation did not exist for the Cretaceous of that ocean basin, and the modern calcareous nannoplankton zonations (Sissingh, 1977; Perch-Nielsen, 1985) had not evolved. Although the same name may exist for a zone (e.g., Eiffellithus turriseiffelii Zone), it was used in the 1970s for a broader concept (Upper Albian by Thierstein, 1974; upper Albian-lower Cenomanian by PerchNielsen, 1985) or for a different part of the time scale.

As some species concepts have evolved, modern treatment requires a detailed reexamination, especially in the case of calcareous nannoplankton. In several cases this is warranted anyway because important questions of age remain unresolved.

\section{Leg by Leg Results}

Upper Maestrichtian (Abathomphalus mayaroensis Zone) faunas were encountered at Sites 216 and 217 and a lower Maestrichtian fauna (Rugotruncana subcircumnodifer Sub- zone) was encountered at Site 217 during Leg 22 (von der Borch, Sclater, et al., 1974; Gartner et al., 1974). Faunas from Sites 211 and 212 could not be integrated into any zonal scheme.

Site 235 (Leg 24) yielded an upper Maestrichtian calcareous nannofossil flora but no foraminifers.

During Leg 25, Site 239 yielded an Upper Cretaceous benthic foraminifer fauna only. The sequence was dated as probably Campanian on calcareous nannoplankton. Site 241 has an Upper Cretaceous section but lacks planktonic foraminifers. The Campanian-lower Senonian age is based on poor calcareous nannoplankton recovery. Cretaceous foraminifers were recovered at four sites on Leg 25: Sites 255, 256, 257, and 258 (Herb, 1974).

Site 255 is on Broken Ridge and is of great importance to Kerguelen Plateau studies because the two plateaus are, in part at least, conjugate across the Southeast Indian Ocean Ridge, and they were part of one unit until it was split by seafloor spreading in the Eocene (Le Pichon and Heirtzler, 1968; Houtz et al., 1977). Unfortunately, the Broken Ridge samples are lithified limestone, and the Santonian-Campanian age is based on calcareous nannoplankton and tentative thin section identifications of a few planktonic foraminifers.

Site 256 is in the Wharton Basin. An Albian (possibly Cenomanian) age was assigned to clays in this hole. Site 257 in the Perth Abyssal Plain (Wharton Basin) also yielded Albian and possibly Campanian faunas based on the tentative identification of Globotruncana cf. elevata (Brotzen). Site 258 (Naturaliste Plateau) gave an Albian-Cenomanian fauna from an argillaceous sequence and a Turonian-Santonian fauna from a nannofossil-chalk sequence. Only a few samples yielded well-preserved faunas.

Herb (1974) referred to the faunas throughout these sites as being of low diversity and took them to be cool-water assemblages. Keeled globotruncanid content was highest (higher than $20 \%$ ) in the Santonian.

Leg 27 produced a considerable body of Cretaceous paleontological results, including those on benthic faunas from Sites 260 and 261 (Upper Cretaceous: Krasheninnikov, 1974a; Lower Cretaceous: Kuznetsova, 1974); Sites 259 and 261 (Lower Cretaceous: Bartenstein, 1974); and Sites 259, 260, and 263 (Aptian-Albian: Scheibnerova, 1974). Planktonic foraminifers (Krasheninnikov, 1974b) were recovered from Sites 259 and 260 and are Aptian and Albian, dominated by Hedbergella spp. in the planktonic foraminifers.

From Leg 28, Site 264 on the southern flank of the Naturaliste Plateau, was the only hole to encounter Cretaceous faunas. They are Cenomanian-Campanian (Hayes, Frakes, et al., 1975) and are dominated by Heterohelix and Hedbergella spp.

In addition to DSDP and ODP data, there are a few results from dredge and core samples from the region (Burckle et al., 1967; Quilty, 1973; Bassias et al., 1987).

\section{Site by Site Results}

Table 2 summarizes the interval and thickness data for the holes discussed below.

The section at Site 211 consists of $17.1 \mathrm{~m}$ of sediment (411.5-428.6 mbsf; water depth, $5535 \mathrm{~m}$ ) identified as Maestrichtian and Campanian. The section consists of "rapid alternations of red, cream, and grey nannofossil-rich clays, nannofossil clay, and nannofossil ooze" (Von der Borch, Sclater, et al., 1974) and incorporates a few altered volcanic glass/ash beds. It overlies basaltic basement and is overlain by a brown clay unit from which it is separated by a diabase sill.

The foraminifer faunas (McGowran, 1974) from the three cores (22-211-12, 22-211-13, and 22-211-14) are barren of 
Table 2. Location, water depth, interval, and thickness data for Cretaceous sections intercepted in the Indian Ocean by DSDP and ODP activities.

\begin{tabular}{lrrrrr}
\hline Site & Latitude & Longitude & $\begin{array}{c}\text { Water } \\
\text { depth }(\mathrm{m})\end{array}$ & Interval (mbsf) & $\begin{array}{c}\text { Thickness } \\
(\mathrm{m})\end{array}$ \\
\hline 211 & $9^{\circ} 46.5^{\prime} \mathrm{S}$ & $102^{\circ} 41.9^{\prime} \mathrm{E}$ & 5535 & $411.5-428.6$ & 17.1 \\
212 & $19^{\circ} 11.3^{\prime} \mathrm{S}$ & $99^{\circ} 17.8^{\prime} \mathrm{E}$ & 6243 & $430.5-516.0$ & 85.5 \\
216 & $1^{\circ} 27.7$ ' & $90^{\circ} 12.5^{\prime} \mathrm{E}$ & 2247 & $332.0-457.0$ & 125.0 \\
217 & $8^{\circ} 55.6^{\prime} \mathrm{N}$ & $90^{\circ} 32.3^{\prime} \mathrm{E}$ & 3020 & $420.0-664.0$ & 244.0 \\
235 & $3^{\circ} 14.6$ ' & $52^{\circ} 41.64^{\prime} \mathrm{E}$ & 5130 & $646.0-684.0$ & 38.0 \\
239 & $21^{\circ} 17.67^{\prime} \mathrm{S}$ & $51^{\circ} 40.73^{\prime} \mathrm{E}$ & 4971 & $319.3-320.0$ & 0.7 \\
241 & $2^{\circ} 22.24^{\prime} \mathrm{S}$ & $44^{\circ} 40.77^{\prime} \mathrm{E}$ & 4054 & $626.0-1174.0$ & 548.0 \\
249 & $29^{\circ} 56.99^{\prime} \mathrm{S}$ & $36^{\circ} 04.62^{\prime} \mathrm{E}$ & 2088 & $172.0-408.0$ & 236.0 \\
250 & $33^{\circ} 27.74^{\prime} \mathrm{S}$ & $39^{\circ} 22.15^{\prime} \mathrm{E}$ & 5119 & $* 690.0-720.0$ & $* 30.0$ \\
255 & $31^{\circ} 07.87^{\prime} \mathrm{S}$ & $93^{\circ} 43.72^{\prime} \mathrm{E}$ & 1144 & $75.0-108.5$ & 33.5 \\
256 & $23^{\circ} 27.35^{\prime} \mathrm{S}$ & $100^{\circ} 46.46^{\prime} \mathrm{E}$ & 5361 & $* 150.0( \pm 25)-248.3$ & $100.0+$ \\
257 & $30^{\circ} 59.16^{\prime} \mathrm{S}$ & $108^{\circ} 20.99^{\prime} \mathrm{E}$ & 5278 & $* 85.0-258.0$ & 4150.0 \\
258 & $33^{\circ} 47.69^{\prime} \mathrm{S}$ & $112^{\circ} 28.42^{\prime} \mathrm{E}$ & 2793 & $114.2($ Hole $258 \mathrm{~A})-525.0(\mathrm{Hole} 258)$ & 411.0 \\
259 & $29^{\circ} 37.05^{\prime} \mathrm{S}$ & $112^{\circ} 41.78^{\prime} \mathrm{S}$ & 4696 & $60.0-304.0$ & 244.0 \\
260 & $16^{\circ} 08.67^{\prime} \mathrm{S}$ & $110^{\circ} 17.92^{\prime} \mathrm{E}$ & 5702 & $147( \pm 9)-323.0$ & $176.0+$ \\
261 & $12^{\circ} 56.83^{\prime} \mathrm{S}$ & $117^{\circ} 53.56^{\prime} \mathrm{E}$ & 5667 & $142.0-508.7$ & 367.0 \\
263 & $23^{\circ} 19.43^{\prime} \mathrm{S}$ & $110^{\circ} 58.81^{\prime} \mathrm{E}$ & 5058 & $123.0( \pm 5)-746.0$ & $623.0+$ \\
264 & $34^{\circ} 58.13^{\prime} \mathrm{S}$ & $112^{\circ} 02.68^{\prime} \mathrm{E}$ & 2876 & $169.0-215.5$ & $* 46.5$ \\
738 & $62^{\circ} 42.56^{\prime} \mathrm{S}$ & $82^{\circ} 47.26^{\prime} \mathrm{E}$ & 2253 & $377.0-496.0$ & 119.0 \\
\hline
\end{tabular}

*May include basement.

planktonic species, and contain a diverse fauna of small, early growth phases of both calcareous and agglutinated foraminifers. Inoceramus was present and the unit was correlated with the Korojon Calcarenite of Western Australia (Belford, 1960) on the basis of a few benthic foraminifers.

The age assignment is based on calcareous nannofossils, which show signs of dissolution, leading to a reduced diversity. Core 12 is upper Campanian-lower Maestrichtian on the basis of the presence of Quadrum trifidum (Stradner), which is lacking from Core 22-211-13 and the top of Core 22-211-14. Aspidolithus parcus parcus (Stradner) also is present, indicating a lower-middle Campanian age, the Eiffellithus angustus Zone. The total nannofiora consists of 10 species (Gartner, 1974), about $20 \%$ of what could be expected. This reduced diversity was postulated to be caused by either low initial diversity at high latitudes or considerable postdepositional dissolution (the present location is well below the CCD). Initial deposition may have been at shallower than abyssal depth, with later deposition by current action, which can be expected to effect some sorting.

Site 212 recovered a $51.5 \mathrm{~m}$ (430.5-482 mbsf; water depth, $6243 \mathrm{~m}$ ) section of nannofossil chalk. There is a gradation in this unit from light olive gray in color near the base to grayish orange pink in the upper $13-14 \mathrm{~m}$. This is accompanied by an uphole decrease in foraminifer content from $30 \%$ near the base to $1 \%-2 \%$ at the top. Cores 22-212-29 (lower calcareous parts) to -35 are included in this section, which overlies zeolitic clay and basaltic basement.

The foraminifer fauna (to Core 22-212-35) is characterized by small, abundant heterohelicids, no warm-water indexes, and a fauna dominated by Globigerinelloides, Hedbergella, and Heterohelix. Globotruncanella cf. citae (Bolli) indicates a Campanian-Maestrichtian age. Core 22-212-36 contains a deep-water, agglutinated benthic fauna (dominantly of unilocular and bilocular forms).

Calcareous nannofossils occur throughout the Upper Cretaceous section, but Bukry (1974a) and Gartner (1974) make different interpretations of the flora. Bukry identified the upper Maestrichtian index Nephrolithus frequens Gorka throughout Cores 22-212-31 to -35 in "well diversified coccolith assemblages," accompanied sporadically by Markalius astroporus and Kamptnerius magnificus Deflandre. Although he agrees with the upper Maestrichtian age determination,
Gartner recorded $N$. frequens as sporadic, regarded the age as "an enigma," and stated that the flora is dominated by long-ranging forms. He regarded the flora as low in diversity for a time interval that elsewhere includes a very diverse flora. Radiolaria are absent from the Cretaceous sequence.

Pimm (1974) discussed the anomaly of common calcareous units well below the $C C D$, each representing a brief time interval. The total sediment section is anomalously thick (516 $\mathrm{m})$ compared with most sedimentary sequences in the vicinity $( \pm 100 \mathrm{~m})$. He suggested that the site was below the CCD in the upper Maestrichtian and that the sediments, represented by the fauna and flora, were redeposited from areas to the west that may have been above the CCD briefly.

Site 216 penetrated a thick $(125 \mathrm{~m})$ upper Maestrichtian sequence (332-457 mbsf; water depth, $2247 \mathrm{~m}$ ). The lower $4 \mathrm{~m}$ are included but are taken here as upper Maestrichtian. Three subunits were recognized within the Maestrichtian, and the entire sequence overlies basaltic basement. Subunit 1C (332348 mbsf; Cores 22-216-23 to -24) consists of $17 \mathrm{~m}$ of light gray glauconitic clay composed primarily of silt-sized micarb grains with some foraminifers, nannofossils, clay, and glauconite (the apparent conflict of two different definitions in one sentence derives from the site report; Von der Borch, Sclater, et al., 1974). Subunit 2A (348-396 mbsf; Cores 22-216-25 to -29) is made up of $48 \mathrm{~m}$ of greenish gray, glauconitic, volcanic, clay micarb chalk. Subunit 2 B (396-457 m; Cores 22-216-30 to -36 ) is akin to Subunit $2 \mathrm{~A}$, but it contains a higher content of volcanic clay and volcanic glass and less glauconite.

The Upper Cretaceous at Site 216 (McGowran, 1974) is generally of a shallow-water (shelf facies) aspect. The foraminifer faunas in the section between Cores 22-216-25 and -35 are usually sparse, but they do contain diverse benthic foraminifers and a low proportion of planktonic species. Below 22-216-25, Globotruncana is absent. In addition to foraminifers, the benthic component includes echinoids, the bivalve Inoceramus, and ostracods, all consistent with the shelf concept. The planktonic fauna, only a small proportion of the total, is characterized by Heterohelix, Guembelitria, and Hedbergella accompanied by Globotruncanella citae (Bolli) (Core 22-216-25 and -26) and Globotruncana arca (Cushman) (Core 22-216-25 and above). Sample 22-216-24-CC and Cretaceous samples above are characterized by "unusually common" Abathomphalus for this part of the section. Core 
22-216-24 appears to present a similar shelf environment to the cores below, but Core $22-216-23$ is of a significantly deeper facies reflecting a major subsidence within the upper Maestrichtian.

Calcareous nannofossils from Cores 22-216-27 to -34 (Bukry, 1974a) contain an upper Maestrichtian flora including Nephrolithus frequens Gorka, Archangelskiella cymbiformis Vekshina (the section at Site 216 is surprisingly like that at Site 747 , even to the confusion over the situation prevailing at the Cretaceous/Tertiary boundary), and Kamptnerius magnificus (Deflandre). Thus, all but Cores 22-216-35 and -36 are Maestrichtian, and all belong to the $N$. frequens Zone. Diversity is low (Gartner, 1974), but whether this is the result of the high latitude or the shallow site of deposition is unclear. Paleolatitude considerations (Von der Borch, Sclater, et al., 1974) would not support the concept of high latitude at the time of deposition as paleolatitude was only some $35^{\circ}-40^{\circ} \mathrm{S}$. The shallow-water scenario may be sufficient to explain the features of the nannofiora. Cores 22-216-30 to -32 also contain diatoms and silicoflagellates and Cores 22-216-30 and -31 contain Radiolaria of Maestrichtian age (Johnson, 1974).

The Cretaceous/Tertiary boundary at this site is marked by a disconformity representing a 2-m.y. gap between the Danian and the Cretaceous. The level of the boundary is debatable. Von der Borch, Sclater, et al. (1974) state that it lies at $22-216-23-2,105 \mathrm{~cm}$, where there is a change in sediment structure. Gartner (1974) conducted a very detailed analysis and, although agreeing with the time interval represented by the disconformity, would probably place the boundary lower, as he recorded Danian down to 22-216-23-2, $117 \mathrm{~cm}$. He ascribed the boundary not to erosion of the Maestrichtian but to nondeposition of the lower Danian.

At Site 217 the thickest Leg 22 Cretaceous section was recovered $(244 \mathrm{~m}$ between 420 and $664 \mathrm{mbsf}$ in water depth of $3020 \mathrm{~m})$. It contains three lithologic subunits. Subunit 2C (420-480 mbsf, Cores 22-217-17 to -22) consists of $60 \mathrm{~m}$ of nannofossil ooze chalk, differentiated from the units above by being mottled and banded of grayish orange pink, very light gray, light brown, and yellowish gray color. Moderate to intense bioturbation, a marked drop in foraminifer concentration to $1 \%-3 \%$, and the presence of predominantly fragmented nannofossils are characteristic. Subunit 2D (480-600 mbsf; Cores $22-217-23$ to -35 ) consists of $120 \mathrm{~m}$ of light gray carbonate siltstone (480-500 mbsf), grading downhole to light gray and greenish gray shelly micarb chalk (510-555 mbsf) and siliceous micarb chalk below. The unit has a higher Inoceramus content in the shelly part. Recognizable microfossils are much less abundant and the rock is consolidated. Nodular chert is common below $550 \mathrm{~m}$. Unit 3 (600-664 mbsf; Cores 22-217-36 and -37 and Cores 22-217A-12A-17a) contains $64 \mathrm{~m}$ of sediment and comprises a complex unit of dolomite sand, chert, and shelly micarb chalk. The shelly micarb content decreases downsection, and this component is absent below $635 \mathrm{~m}$. The unit consists of individual beds $10-30 \mathrm{~cm}$ thick, clearly differentiated and, in places, cross-laminated.

Planktonic foraminifer studies (McGowran, 1974) led to a threefold subdivision of the Upper Cretaceous sequence. Cores $22-217-17$ to -23 belong to the upper Maestrichtian Abathomphalus mayaroensis Zone with a fauna changing through the interval. At the top (Cores 22-217-17 and -18), there are common robust calcareous and agglutinated benthic foraminifers, probably a result of the dissolution of some of the planktonic foraminifers. Preservation of planktonic foraminifers deteriorates upsection, but diversity increases; and in Cores $22-217-17$ and -18 the fauna includes a full-diversity, low-latitude fauna of doubly and singly keeled globotrun- canids, Rugoglobigerina, and large heterohelicids. This is an oceanic fauna affected by deepening to below the lysocline.

Below Core 22-217-23, A. mayaroensis is absent but $A$. intermedius is still present in Core 22-217-24. In the interval to $22-217-30$, Inoceramus is common and is accompanied by Rugoglobigerina rugosa s.l. as the dominant planktonic species. Diversity is lower than above; singly keeled Globotruncana is virtually absent, but doubly keeled forms (especially G. arca) are still present. The proportions of Inoceramus and benthic foraminifers decrease upward, preservation deteriorates upward, and planktonic components and evidence of corrosion increase upward. The assemblages are not fully tropical, and the environment of deposition was outer shelf or deeper. This unit belongs to the $A$. mayaroensis Zone in Core 22-217-23 and to the middle Maestrichtian below. Differentiation of an entire array of Maestrichtian Zones is not possible, but it is probable that this middle unit is entirely Maestrichtian.

From Core $22-217-31$ to -36 , there is evidence of a change from initially inner shelf to ultimately outer shelf conditions. Preservation is good without evidence of solution. Benthic foraminifers are more common than above, but their proportion decreases upsection. The benthic fauna is a diverse, mixed calcareous/agglutinated one accompanied by Inoceramus, echinoids, sponges, and ostracods. The planktonic association consists of Archaeoglobigerina-Globotruncana linneiana-Globigerinelloides-Heterohelix. Globotruncana arca is prominent in the upper part of the sequence. This unit is Campanian. Below Core 22-217-36 no useful microfossils were recorded.

Pessagno and Michael (1974) accepted McGowran's (1974) allocation of cores above Core 22-217-23 to the A. mayaroensis Subzone of Pessagno (1967) but added 22-217-24-1, 80-82 $\mathrm{cm}$, to the zone and attributed $22-217-24-2,80-82 \mathrm{~cm}$, to $-27-3,71-73 \mathrm{~cm}$, to the lower Maestrichtian Rugotruncana subcircumnodifer Subzone of that scheme. Pessagno (1974) recognized a threefold division of the Maestrichtian: an upper A. mayaroensis Subzone (equivalent to the A. mayaroensis Zone of most authors), a G. ganserri Subzone (equivalent to the middle Maestrichtian G. gansseri Zone of many authors), and a $R$. subcircumnodifer Subzone (equivalent to differently titled lower Maestrichtian zones of many authors). Thus, in this section, the middle Maestrichtian has not been identified separately.

It is clear from the above data that faunas from the uppermost Maestrichtian unit of McGowran (Cores 22-217-17 to -22$)$ can be allocated to Sliter's $(1972,1977)$ Tethyan planktonic foraminifer assemblage. The middle unit (Cores 22-217-23 to -30 ) probably is of Sliter's Transitional assemblage and the lower unit (Cores 22-217-31 to -36) may be Austral or grading upward to Transitional. This gradation reflects a trend toward increasing temperature with time, perhaps also reflecting the northward movement of the site of deposition with time.

There was no detailed analysis of calcareous nannoplankton from this site, but Bukry (1974b) ascribed an upper Maestrichtian age (actually Upper Cretaceous; Micula mura Zone) to floras from Cores 22-217-17 and -18. Radiolaria and other microfossils appear to be absent from this section.

Site 235 recovered no Cretaceous forms within the sediment column; however, the basalt in Cores 24-235-17, -18, and -20 contained layers and veins of metamorphosed finegrained sediment (Fisher, Bunce, et al., 1974) (described by Roth, 1974, as "inclusions in the basalt"), which contained no foraminifers or Radiolaria but did yield the calcareous nannoplankton Micula decussata Vekshina, M. mura (Martini), 
Markalius inversus (Deflandre), and Prediscosphaera cretacea (Archangelsky), indicating an upper Maestrichtian age.

Site 239 (Simpson, Schlich, et al., 1974) recovered approximately $0.7 \mathrm{~m}$ of Cretaceous sediment immediately overlying basalt. It is included in Subunit IIB, which is a brown clay, modified sporadically to a nannofossil ooze with varying amounts of clay. Its color is grayish green in places. It is separated from overlying Subunit IIA by its fineness, as it lacks a silt-size fraction.

Although there are no discernible volcanic ash horizons, the volcanic contribution is important. All the Cretaceous sediments occur in Core 25-239-19, below Section 2, $74 \mathrm{~cm}$. Sedimentation began above the CCD, but the area soon sank below it. The contact between the Cretaceous and Paleocene parts of this unit must mark an unconformity of $\sim 7-11 \mathrm{~m}$.y. duration.

Foraminifers are all benthic; faunas are diverse, including both calcareous and agglutinated forms, but lacking nodosariids. Calcareous nannoplankton are not common nor diverse, and floras are consistent with an upper Campanian age. Müller (1974) concedes a possible lower Maestrichtian age. Deposition was probably on the lower to middle part of the continental slope, and the foraminifer fauna may be of shallower origin, brought in as turbidites. Very few paleoceanographic data for the Cretaceous were generated by this hole.

Site 241 was drilled at the foot of the continental slope of Africa (Simpson, Schlich, et al., 1974) and penetrated a total sediment thickness of $1174 \mathrm{~m}$ without reaching basement, which may be $2000 \mathrm{mbsf}$. The Cretaceous was encountered in Cores 25-241-22 to -29 , representing a cored interval of $72 \mathrm{~m}$ (with $55 \%$ recovery) over the $548 \mathrm{~m}$. The Cretaceous sequence is all encompassed in Unit II, a greenish and brown claystone with minor nannofossil-rich claystone, silty clay, and calcareous sandstone. Deposition appears always to have been below the $\mathrm{CCD}$.

Foraminifer faunas were disappointing: there were virtually no planktonic foraminifers preserved; many samples were barren; many had only a few dissolution-resistant, nondiagnostic, agglutinated faunas; and even the best samples have only calcareous benthic foraminifers, of which few have any stratigraphic significance. Sigal (1974) identified Turonian or lower Senonian, Santonian to Campanian, and upper Senonian species.

Calcareous nannoplankton were more productive as some horizons were rich in these fossils. Cores $25-241-22$ to -27 $(626-986 \mathrm{~m})$ are Campanian and $25-241-28$ is "early Senonian." Core 25-241-29 is barren. Based on the species listed, Watkins (pers. comm., 1988) suggests that the flora would now be regarded as uppermost Campanian in age. Bukry (1974b) referred Cores 25-241-22 to -25 to the Tetralithus (now Quadrum) trifidus Zone. Radiolaria are virtually absent. The Cretaceous sequence is overlain by the Eocene, with an unconformity representing $15-20 \mathrm{~m} . \mathrm{y}$.

Site 249 contained a thick $(236 \mathrm{~m})$ section of Cretaceous sediment (Cores 25-249-16-2, $150 \mathrm{~cm}$, to $-32-\mathrm{CC}$ ) assigned to lithologic Units II and III. Unit III is divided into lower Subunit IIIB and upper Subunit IIIA.

Unit II is a brown and gray, foraminifer, clay-rich, nannofossil chalk, extending from $25-249-16-2,150 \mathrm{~cm}$, to $-23-2,130$ $\mathrm{cm}$, a thickness of $115 \mathrm{~m}$ (172-287 mbsf). The upper boundary is an unconformity of approximately $40-50 \mathrm{~m} . \mathrm{y}$. where the Cretaceous is overlain by the middle Miocene. Sediments in Cores 25-249-16 and -17 contain upper Maestrichtian foraminifer faunas with Abathomphalus mayaroensis, Trinitella scotti, and Contusotruncana contusa subsp. Below 25-249-21 sediments are upper Campanian, suggesting that Cores 25 249-18 to -21 (part), or just above, are lower Maestrichtian.
Diversity seems high, with common globotruncanids and diverse heterohelicids, probably equating with Sliter's Tethyan faunal province (Sliter, 1977) of warm-water aspect.

Calcareous nannoplankton, which are abundant and well preserved, support the foraminifer results in this interval almost exactly. Bukry (1974b) provides a more detailed discussion than Müller (1974) that recognizes the following subdivisions:

1. ?Nephrolithus frequens Zone down to Core 25-249-17-3, 100-102 cm;

2. Tetralithus (now Quadrum) trifidum Zone, from Cores $25-249-17-4,130-131 \mathrm{~cm}$, to $-21-3,60-61 \mathrm{~cm}$; and

3. Eiffellithus angustus Zone, from Cores 25-249-21-5, $60-61 \mathrm{~cm}$, to -23 .

Radiolaria are present but very rare.

Subunit IIIA consists of gray and olive silty claystone (Simpson, Schlich, et al., 1974) and volcanic siltstone. It extends from 25-249-23-3, $130 \mathrm{~cm}$, to -29-1, $100 \mathrm{~cm}$ (approximately), a thickness of $65 \mathrm{~m}$, represented in seven cores. Lithology varies quite widely but grain size normally contains a significant component in the silt-size range. Subunit IIIA is separated from Unit II by an unconformity (Campanian/ Cenomanian) of some 12-15 m.y. Simpson, Schlich, et al. (1974) refer part of this unit between Samples 25-249-23-3, 3-6 cm, and -24-1, 136-139 cm, to the "middle" Cretaceous, and between Samples 25-249-25-2, 100-102 cm, and -29-1, 100 $\mathrm{cm}$, to the Lower Cretaceous.

The mid-Cretaceous interval has a rich radiolarian fauna and few good foraminifer faunas, but variations in fossil content are very erratic and few generalizations can be made. Three samples within Core 25-249-23-4 contained a planktonic fauna of "Globigerinidae" and numerous Gavelinella (benthic). A sample at 25-249-23-3, 3-6 cm, very close to the top of this unit, yielded a fauna of several species of Hedbergella, Planomalina, and Ticinella, taken to be of Vraconian (upper Albian) or possibly lower Cenomanian age. Although it contains a noteworthy planktonic foraminifer fauna, there is no evidence that this mid-Cretaceous section contains calcareous nannoplankton.

The lower part of this subunit (included in the Lower Cretaceous) is difficult to disaggregate and has not produced satisfactory foraminifer faunas. Bukry (1974b) reported on the calcareous nannofossils that occur in Cores 25-249-28 and -29 of this interval and extend downhole into Subunit IIIB. Bukry suggested a lower Aptian age, based partly on the absence of Albian and younger forms. Simpson, Schlich, et al. (1974) supported this age (perhaps a little older; e.g., Barremian) for the upper part of Core 25-249-26 on the basis of "globigerinids" and ostracods.

Subunit IIIB is finer grained than Subunit IIIA, lacking silt-size particles. It is harder and more difficult to disaggregate. As noted above, it contains a few Neocomian ostracods and foraminifers, but details are difficult to obtain from the site report. There is a conflict in dating because the site report (foraminifers) records $25-249-26$ to -31 as being Neocomian (Valanginian or Hauterivian). This age assignment has recently been confirmed after a thorough study of the benthic foraminifers from these cores (Riegraf, 1989) and comparison of the benthic faunas with age-equivalent faunas from many DSDP sites (Riegraf and Luterbacher, 1989). Bukry (1974b), however, on the basis of calcareous nannoplankton, regards the interval in Cores 25-249-28 to -31 as lower Aptian. This conflict is not resolved, but the recent benthic foraminifer studies (Riegraf, 1989; Riegraf and Luterbacher, 1989) have helped considerably in clarification. 
This section is an important one, one of the few in the Indian Ocean recording more than just the Campanian-Maestrichtian; and it assumes extra importance because of its Lower Cretaceous component. It needs detailed study, particularly of Radiolaria and nannoplankton in the "middle" and Lower Cretaceous, taking account of great advances in microfossil biostratigraphy that have occurred in recent years.

The Cretaceous at Site 250 is very poorly preserved, and Herb (1974) did not even bother to incorporate the site in his review of DSDP Leg 26 Cretaceous planktonic foraminifers. The Cretaceous/Tertiary boundary is taken at about $690 \mathrm{mbsf}$ within lithologic Unit IV, a semilithified detrital brown clay. Below 691 $\mathrm{m}$, it contains zeolites and nodules of $\mathrm{Fe}$ and $\mathrm{Mn}$ oxides. Age control is very poor in the interval (638-703.5 mbsf) assigned to Unit IV. The upper part is lower Miocene (Core 26-250-16; 634-643.5 mbsf) and the lowest part (Core 26-250-23; 700.5-710 mbsf) is Upper Cretaceous. The boundary must be at an unconformity, and the minor lithologic change at 691 mbsf seems a reasonable level at which to place it.

Lithologic Unit ? (Cores 26-250-24 and -25; 703.5-725.5 mbsf) is a semilithified olive gray clay essentially barren of fossils. The foraminifer faunas, such as they are, are dominated by a few agglutinated species. The bivalve Inoceramus is an important component. The Upper Cretaceous age appears to be based on the presence of Anomalina nelsoni Berry. Calcareous nannoplankton are rare and very poorly preserved. Thierstein (1974) dismissed them very briefly. They are said, in the site report (Davies, Luyendyk, et al., 1974) to be Coniacian possibly, although this is neither noted nor documented in the specialist reports. Radiolaria (Riedel and Sanfilippo, 1974) are present, but they indicate a Barremian or younger Cretaceous age.

Sedimentation in the Cretaceous was below the CCD, and the dissolution of fossils is almost complete. The basis for the Coniacian age seems weak and the calcareous nannoplankton need reexamination.

Hole 255 on Broken Ridge, drilled through $33.5 \mathrm{~m}$ (Cores 26-255-8 through -11) of hard Upper Cretaceous limestone, did not reach basement, and no realistic estimate of depth to basement below the bottom of the hole was given in the site report (Davies, Luyendyk, et al., 1974).

The limestone (lithologic Unit 3 ) dips at $15^{\circ}-30^{\circ}$ to the hole (assumed vertical) and consists of fossiliferous biomicritic carbonate with four chert bands, $6-18 \mathrm{~cm}$ thick. Foraminifers and Radiolaria occur in the micrite, and there are remains of Inoceramus and other bivalves and crinoids. Glauconite and pyrite are present. The foraminifer fauna includes Globigerinelloides, abundant Hedbergella, and rare Globotruncana. It was too solid for disaggregation. As noted in Davies, Luyendyk, et al. (1974), it may be a cool-water deposit, belonging to Sliter's (1977) Austral or Transitional Faunal Province. Deposition was not below the CCD but more likely on the outer continental shelf or continental slope. Herb (1974) discussed the foraminifers briefly.

Three poorly preserved calcareous nannoplankton assemblages were recovered and indicate a Santonian age by comparison with Site 258 on the Naturaliste Plateau, slightly older than the Santonian part of the Gingin Chalk (Belford, 1960).

Calcareous nannoplankton (Thierstein, 1974) have been identified in the limestone unit and have been seen abundantly where reworked into the Eocene in Core 26-255-7. There is little discussion of the nannofossils, but 13 species were identified and assigned to the Marthasterites furcatus Zone. Micula decussata is abundant in Sample 26-255-11-CC and occurs in a core-catcher sample in the Cretaceous. Radiolaria (Riedel and Sanfilippo, 1974) occur but were not useful in age assignment.
This site was the only one to encounter Cretaceous sediments on Broken Ridge, taken as a conjugate of Northern Kerguelen Plateau. Unfortunately, not enough data can be extracted from the biostratigraphy to allow adequate comparison with the sections of the Northern and Southern Kerguelen Plateaus.

Site 256 was drilled in deep water $(5361 \mathrm{~m})$ and the section was divided (Davies, Luyendyk, et al., 1974) into two units: a brown to grayish brown detrital clay (Unit 1) overlying basalt (Unit 2). The Cretaceous/Tertiary boundary was not identified but occurs between 26-256-5-2, 35-39 cm (125.5 mbsf), and 26-256-7-CC (218.5 mbsf). This is an unconformable contact with no lithological expression. The lower boundary of the Cretaceous sedimentary sequence is placed at $248.3 \mathrm{mbsf}$ in Sample 26-256-9-1, $130 \mathrm{~cm}$.

Cretaceous foraminifers are mainly unilocular and bilocular agglutinated forms of little stratigraphic significance. The few planktonic species (Hedbergella only), low in the interval, are also of little significance other than to indicate a Cretaceous age.

Calcareous nannoplankton are more useful for stratigraphic purposes in this hole. All nannoplankton recovered, although moderately to strongly affected by dissolution, are from the upper Albian Eiffellithus turriseiffelii Zone (Thierstein, 1974; Bukry, 1974c), consistent with the foraminifer results (Herb, 1974).

The foraminifer fauna, discussed in Davies, Luyendyk, et al. (1974), is consistent with cool-water conditions of deposition, the first time this important observation was made in the Indian Ocean drilling program.

Site 257 was drilled in the Perth Abyssal Plain in $5278 \mathrm{~m}$ (Davies, Luyendyk, et al., 1974). The top of the Cretaceous section is not defined but is above Core 26-257-4-CC, which contains Cretaceous Radiolaria. Cores 26-257-1 to -3 are barren of diagnostic fossils. The base of the Cretaceous section is at 257.8 mbsf where it overlies basalt. The sedimentary section is included in one unit, which is divided into four subunits.

Subunit $1 \mathrm{~A}$ is taken as $185 \mathrm{~m}$ thick (the base was not cored, and therefore the boundary is somewhat arbitrary) and consists of soft, dark brown zeolitic clay. It is essentially carbonate free (but see below). Cores $26-257-1$ to -6 were taken in this subunit. Subunit $1 \mathrm{~B}$ is of red and gray coccolith detrital clay. Carbonate occurs throughout the unit, and there is a coccolith chalk at 240 mbsf and minor coccolith ooze horizons elsewhere. The base of the subunit is at 249 mbsf within Core 26-257-9. Subunit $1 C$ is the lowermost $13 \mathrm{~cm}$ of the Cretaceous section and consists of red and reddish brown clay. Subunit 1D contains occasional foraminifer faunas. Sample 26-257$5-1,140-142 \mathrm{~cm}$, included Globotruncanita cf. elevata (Brotzen), taken as an index of Campanian age. Cores 26257-5 and -6 contain Haplophragmium cf. aequale (Roemer), which supports the Cretaceous age assignment. Cores 26257-1 to -4 contain a few poorly preserved agglutinated species, apparently of no diagnostic value.

Cores 26-257-7 to -9 contain calcareous foraminifers, those in Core $26-257-8$ being moderately abundant and well preserved. Those from adjacent cores show effects of dissolution, suggesting that Core $26-257-8$ was deposited at the time of deepest CCD. The planktonic foraminifer fauna in Cores 26-257-8 and -9 includes primitive forms of Ticinella $(T$. aff. raynaudi raynaudi and $T$. cf. roberti [Gandolfi] Herb, 1974) in addition to Globigerinelloides caseyi (Bolli, Loeblich and Tappan) and Hedbergella spp. These are consistent with a middle Albian age. Deeper sections cannot be dated on the few "primitive" agglutinated forms contained in the core samples studied. 
The calcareous nannoflora is best developed in Samples 26-257-7-CC and $-8-1,139 \mathrm{~cm}$, where dissolution effects are minimal. Below Core 26-257-9, all calcareous nannoplankton have been dissolved. The age of the floras studied from the calcareous material is middle Albian (Prediscosphaera cretacea Zone; Thierstein, 1974). It is a diverse flora, in which Watznaueria barnesae (Black) is dominant. The nominate taxon is present throughout the interval from Samples 26-257$7-1,120 \mathrm{~cm}$, to $-9-2,37 \mathrm{~cm}$. Bukry $(1974 \mathrm{c})$ agrees with the determinations of Thierstein (1974).

Radiolaria (Riedel and Sanfilippo, 1974) occur sporadically throughout Cores $26-257-1$ and -4 to -7 , but they are absent below that. They provide the only evidence of post-Cretaceous deposition at Site 257: Oligocene-Eocene in Core 26257-1. Sample 26-257-4-4, 84-88 cm, contains the most diverse fauna, suggesting an approximately Turonian-Coniacian age (Dictyomitra veneta Zone). This age is in conflict with the foraminifer-based Campanian age for Core 26-257-5, but that was based on a tentative thin-section identification. The radiolarian age seems better based.

Site 257 contains many horizons with calcisphaerulid Pithonella spp. Davies, Luyendyk, et al. (1974) state that Bolli (1974) studied these forms. In fact, Bolli (1974) reported only on those from Leg 27 sites. From Bolli's report they reach maximum diversity and abundance in the Albian, consistent with the estimated age of Cores $26-257-7,-8$, and the upper part of -9 , where they are preserved. The foraminifer fauna was taken (Davies, Luyendyk, et al., 1974) to indicate cold conditions of deposition because of its low diversity. The difference in age between Core 26-257-5 and Cores 26-257-7 and deeper suggests the presence of a significant hiatus somewhere between those cores.

Site 258 (Davies, Luyendyk, et al., 1974) was drilled in Holes 258 and $258 \mathrm{~A}$, in $2793 \mathrm{~m}$ water depth on the northern flank of the Naturaliste Plateau. It penetrated one of the best Cretaceous sequences so far encountered in the Indian Ocean, covering the interval from the middle Albian to the Santonian. The total thickness penetrated was $411 \mathrm{~m}$ between Samples 26-258A-8-6, $120 \mathrm{~cm}$ (114.2 mbsf), and 26-258-25-CC (525 mbsf). Basement was not reached, and the Cretaceous is overlain with marked a unconformity by upper Miocene sediments. The Cretaceous is included in Units 2-5 inclusive.

Unit 2 was divided into two subunits. Subunit 2A (Cores 26-258-5 to -10 and Core 26-258A-9; (114-203 mbsf) consists of gray micarb or foraminifer chalk. Microcrystalline calcite (micarb) makes up $10 \%$ of this subunit, and chert and silicified limestone are characteristic. Subunit 2B (Cores 26-258-11 to $-13 ; 203-263$ mbsf) has a higher $(25 \%-70 \%)$ content of micarb and is described as a micarb coccolith chalk and coccolith micarb chalk. Foraminifers are much less abundant than in Subunit $2 \mathrm{~A}$.

Unit 3 (Cores 26-258-14 and -15; 263-285 mbsf) consists of interstratified green, gray or darker detrital clay, coccolith clay, and coccolith-rich micarb chalk. It grades downhole into Unit 4 (Cores 26-258-15 to -24; 285-514 mbsf), which consists of brownish and olive black ferruginous clay. Unit 5 (Core 26-258-25; 514-525 mbsf), the lowest unit encountered, consists of fine- to medium-grained glauconitic sandstone overlying brown silty mudstone.

Subunit $2 \mathrm{~A}$ contains a low-diversity Coniacian-Turonian foraminifer fauna (Herb, 1974) dominated by globigerinelloid, hedbergellid, and heterohelicid species. Archaeoglobigerina and Whiteinella are important index forms. Globotruncanids and benthic foraminifers are rare, and Inoceramus prisms are a conspicuous feature, especially in the Santonian. The Santonian/Coniacian boundary was placed tentatively between Cores 26-258-5 and -6 (between 133 and $142.5 \mathrm{mbsf}$ ) in an interval that was not cored (Herb, 1974). The fauna was said to be of "extropical transitional" character, probably equivalent to Sliter's (1977) Transitional faunal province. Calcareous nannoplankton from Subunit 2A (Thierstein, 1974) belong to the Marthasterites furcatus Zone, which bridges the Santonian/Coniacian boundary and extends to the top part of Core 26-258-11, in Subunit 2B. Specimens are etched to slightly overgrown.

Turonian foraminifer faunas were recovered from Subunit 2B in Cores 26-258-12 and -13 (as low as Sample 26-258-13-4, $109 \mathrm{~cm}$ ) in bulk samples, but they are rare and of low diversity. Dissolution effects are obvious, reflecting a CCD higher than in Unit 3 and Subunit 2A. Praeglobotruncana predominates (four species) and large Hedbergella are present. The faunas are of middle to upper Turonian age. No lower Turonian was identified and a stratigraphic break was suggested. The Turonian/Cenomanian boundary was identified (Herb, 1974) in Core 26-258-13, between $109 \mathrm{~cm}$ and the core catcher.

Calcareous nannoplankton from Cores 26-258-11 (lower part) to -13 (upper part of Sample 26-258-13-2, $88 \mathrm{~cm}$ ) belong to the Kamptnerius magnificus Zone, which bridges the Turonian/Coniacian boundary. This zone spans a slightly shorter time span than is represented by Subunit $2 B$, the deposition of which began before and ceased after the calcareous nannoplankton defining the zone. Lower but still within the Turonian, the Micula decussata Zone was recorded in Samples 26-258-13-2 (lower part at $128 \mathrm{~cm}$ ) and 26-258-13-4, $9 \mathrm{~cm}$.

Cenomanian foraminifer faunas were reported in Sample 26-258-13-CC and throughout Core 26-258-14, but the identification must be seen as tentative because it is based on the presence of Schackoina cenomana (Schacko) (recorded in sediments older and younger) and a single specimen of Rotalipora reicheli Mornod. The noteworthy characteristics of this fauna are its low diversity and lack of keeled forms, all suggesting cool-water conditions.

There is a conflict between foraminifer and calcareous nannoplankton dates. Both systems agree that Core 26-258-14 is Cenomanian, but Core $26-258-13-\mathrm{CC}$ is regarded as Turonian on the basis of calcareous nannoplankton (Thierstein, 1974), and Cenomanian on foraminifers (Herb, 1974). Some later calcareous nannoplankton zonations (e.g., Roth, 1978) regard the Gartnerago obliquum Zone as entirely within the Cenomanian (and thus consistent with the foraminifer results), whereas Thierstein (1974) took it to extend into the Turonian. Sample 26-258-14-CC was the only sample attributed to the Cenomanian Lithaphridites alatus Zone.

Below Core 26-258-14, all foraminifer faunas were taken (Herb, 1974) to be Albian in age, with marked cool-water characteristics such as domination by small Hedbergella spp. and the lack of key keeled species. Calcareous nannoplankton provided the basis for a more refined stratigraphic zonation, and Cores 26-258-15 to -19 inclusive are referred to the upper Albian Eiffellithus turriseiffelii Zone; those from Core 26258-20 to Sample 26-358-23-CC are in the middle Albian Prediscosphaera cretacea Zone. Deeper Cores 26-258-24 and -25 yielded no microfossils. Radiolaria are present in almost all Cretaceous cores, but in many instances are fragmentary or nondiagnostic (Riedel and Sanfilippo, 1974). Most of the section could be included in the Dictyomitra veneta Zone that spans the Albian-Coniacian. The section at Site 258 records a general warming and shallowing trend from the middle Albian to the Santonian. Initially conditions were quite cool.

Site 259 drilled the third hole in the Perth Abyssal Plain in $706 \mathrm{~m}$ water depth. Cretaceous sediments are included between Samples 27-259-7-4 (60 mbsf) and -33-2, $30 \mathrm{~cm}$ (304.3 
mbsf), and encompass lithologic Units 2-4 of Veevers, Heirtzler, et al. (1974). The Cretaceous overlies basalt basement and is overlain unconformably by Paleocene sediments. This section was subject to detailed paleontological analyses, which involved many fossil (mainly microfossil) groups. Site 259 was, at the time, the best paleontologically studied site in the Indian Ocean.

Unit 2 from Samples 27-259-7-4 (60 mbsf) to -11-CC (103 mbsf) is a brown zeolite clay and zeolitic clay with strongly contorted bedding throughout. Unit 3 from Core 27-259-12 (103 mbsf) to Sample 27-259-17-2, $50 \mathrm{~cm}$ (154 mbsf), is a light and yellowish brown zeolitic nannofossil clay and zeolitic clayey nannofossil ooze. Unit 4 from Samples 27-259-17-2, 50 $\mathrm{cm}$ (154 mbsf), to $-33-2,30 \mathrm{~cm}(304.3 \mathrm{mbsf})$, is a dark greenish gray claystone, highly deformed but partially to completely indurated.

Unit 2 and that part of Unit 3 above Sample 27-259-14-CC are barren of foraminifers; however, below that depth, two very different assemblages exist. From Samples 27-259-14-CC to 27-259-17-3, faunas are diverse and contain dominantly calcareous benthic forms (Scheibnerova, 1974) 63 species in number, with 40 agglutinated species also present. They are typically upper Albian age in comparison with well-developed Australian faunas. Scheibnerova (1974) used these faunas to suggest an informal benthic zonation. She suggested that deposition occurred at upper continental slope depths $(200-600 \mathrm{~m})$, well above the CCD, and that the faunas belong to the Austral Biogeoprovince as defined by Scheibnerova (1971). Planktonic foraminifers (Krasheninnikov, 1974b) occur in significant numbers in Cores 27-259-14 to -17. The fauna is dominated by six species of Hedbergella; Krasheninnikov recorded no other forms, and he regarded this as evidence that Site 259 faunas represent cooler waters than those from Site 260.

The lower assemblage (Bartenstein, 1974) occurs occasionally in Sample 27-259-17-CC to Core 27-259-32, and consists of "primitive" agglutinated forms. Bartenstein (1974) reported on such faunas from Cores 27-259-18 to -33 and quoted a lower Aptian age for Cores 27-259-25 and -26. Cores 27-259-32 and -33 are either lower Aptian or upper Neocomian. All these ages are based on palynology (see below). The faunas are dominated by unilocular and bilocular forms, but multilocular forms are also present. No calcareous forms were recorded in this interval, and deposition probably occurred below the CCD. The deeper samples (Cores 27-259-31 to -33) have a more diverse fauna than the shallower.

Cretaceous calcareous nannoplankton are restricted to Samples 27-259-11-CC to -17-4. All identified species (Proto Decima, 1974) belong to the middle Albian Prediscosphaera cretacea Zone. In the lower three cores, preservation falls off. As with foraminifers, the greatest diversity and best preservation were in Sample 27-259-14-CC. Bukry (1974d) recorded the faunas as belonging to the lower Albian ( $P$. cretacea Zone). He also recorded two species (not age diagnostic in themselves) from Sample 27-259-28, 74-76 cm, the deepest calcareous microfossils recorded from this site.

Renz (1974) reported very poor Cretaceous Radiolaria from Cores $27-259-5$ to -30 , and they provide the basis for placing Cores $27-259-8$ to -11 in the Cretaceous. Wiseman and Williams (1974) examined palynomorphs from Cores 27-259-18 to -33. They suggested a lower to upper Aptian age on the basis of a diverse dinoflagellate flora. The accompanying spores and pollen are consistent with a Neocomian age for Cores $27-$ 259-31 to -33 , somewhat in conflict with the dinoflagellates. Overall, Wiseman and Williams proposed an Aptian age.

Bolli (1974) conducted a detailed study of the calcisphaerulids from the section, including the erection of many new species and one new genus. They occurred in Cores 27-259-12 to -17 and were used to define a middle Albian age. Cores 27-259-8 to -11 contain no Cretaceous fossils other than Radiolaria and their exact position remains a mystery. Veevers, Heirtzler, et al. (1974) placed the boundary between lower and upper Aptian between Cores 27-259-23 and -25, about 220 mbsf.

Site 260 was another hole in deep water $(5702 \mathrm{~m})$ that penetrated a significant Cretaceous sequence with a great deal of paleontological control. Its three lithologic units $(2,3$, and 4) were placed in the Cretaceous. Unit 2 (Cores 27-260-5 to -8; $158-224.5 \mathrm{mbsf}$ ) is a yellowish brown zeolitic clay. It is overlain unconformably by a Cenozoic sequence that is not older than middle Oligocene (a stratigraphic break of at least $30 \mathrm{~m} . \mathrm{y}$. , although it could be much greater). Carbonate is a minor component of this unit, which was deposited at or below the CCD. Unit 3 (Cores $27-260-9$ to $-12 ; 224.5-272$ mbsf) is a brown to orange-pink nannofossil ooze with minor dark clay. There is no evidence of stratigraphic gaps between this unit and the units above or below it. Unit 4 (Core $27-260-13$ to Sample $27-260-18-2,125 \mathrm{~cm} ; 272-322.2 \mathrm{~m}$ ) is a greenish gray nannofossil ooze and clay except for the lower $2 \mathrm{~cm}$, which is brown. Radiolaria form a minor but conspicuous component of this unit. It directly overlies basalt, which probably is a sill rather than basement.

Planktonic foraminifers (Krasheninnikov, 1974b) occur in Samples 27-260-9-1 to -11-CC. The faunas consist completely of Hedbergella and Globigerinelloides, with elements suggesting a late Albian age. The same interval yielded a diverse, stratigraphically significant mid-upper Albian fauna of calcareous and agglutinated benthic foraminifers (Scheibnerova, 1974). Nodosariids are of minor importance, and the faunas have strong links with coeval Australian and Indian faunas. Veevers, Heirtzler, et al. (1974) and Krasheninnikov (1974b) recorded fragments of globotruncanids as high as Core 27260-5, and this is the basis for the Cretaceous age assignment that high in the hole. Krasheninnikov regarded them as reworked and representing faunas of three ages, the youngest of which is Turonian/Coniacian. They are taken as an indication of rapid sedimentation below the $\mathrm{CCD}$ of material brought in by turbidity currents.

Cores $27-260-12$ to -18 contain dominantly agglutinated forms, but a few calcareous species are present. Diversity is much lower than above, and faunas are lower Albian or upper Aptian. Scheibnerova regarded these as representing deposition in less than $100 \mathrm{~m}$ of water, well above the CCD and much shallower than the succeeding faunas, which were deposited at continental slope depths.

Cores 27-260-8 to -11 are barren of calcareous nannoplankton, and deeper cores to the base of the sediment section can be assigned to the Prediscosphaera cretacea Zone, taken by Proto Decima (1974) to be middle Albian. There is a conflict between the age assignments based on calcareous nannoplankton and on benthic foraminifers, which place the deeper cores (27-260-12 to -18) in the lower Albian or upper Aptian. Cores $27-260-13$ to -18 have a much lower diversity and quality of preservation than in cores above, a feature that Proto Decima ascribes to dissolution rather than climate influence. She refers to reworked Aptian, which may, in fact, be in place in an Aptian sequence. This would make the apparently conflicting results more consistent.

Bukry (1974d) has a rather different interpretation of the calcareous nannoplankton, placing Samples 27-260-10-1, 111 $\mathrm{cm}$, to $-11-1,85 \mathrm{~cm}$, in the Albian/Aptian Parhabdolithus angustatus Zone, a full zone older than Proto Decima identified. Sample 27-260-12-2, $54 \mathrm{~cm}$, was assigned to the upper Neocomian Tubodiscus jurapelagicus Zone, and below this sample, to an older Neocomian age (Valanginian or Berria- 
sian). This conflict remains unresolved. It is one in which palynology could play a useful part, but palynology was not attempted on this section.

Radiolaria are common below Core 27-260-11, but ages cannot be assigned to samples below Core 27-260-12. Calcisphaerulids occur occasionally between Cores 27-260-6 and -15. All but those from Core 27-260-6 are Albian or older. Cores $27-260-9$ to -11 yielded an ostracod fauna (Oertli, 1974) and Cores 27-260-9 and -10, fragments of the bivalve Aucellina sp. A (Speden, 1974).

Site 261 in the Argo Abyssal Plain penetrated the oldest sediment known from the Indian Ocean basin, Upper Jurassic red claystone. It was also in very deep water, $5667 \mathrm{~m}$. Most of the section drilled is mainly Lower Cretaceous. The Cretaceous/Tertiary contact is between 104.5 (Core 27-261-4) and 161.5 mbsf (Core 27-261-5), but it is not possible to be more precise than that. It probably is unconformable. The site report (Veevers, Heirtzler, et al., 1974) takes the Cretaceous/ Tertiary contact and that between Unit 2 and Subunit $3 \mathrm{~A}$ to be at $142 \mathrm{mbsf}$, based on the presence of a distinct seismic reflector at that depth. Lithologic Units 3 and 4 are Cretaceous, but Unit 4 also extends into the Jurassic.

Unit 3 was divided into Subunits $3 \mathrm{~A}$ and $3 \mathrm{~B}$. Subunit $3 \mathrm{~A}$ (Cores 27-261-5 to -9; 161.5-209 mbsf) is a soft brown zeolitic clay, almost devoid of stratigraphically significant fossils. Subunit 3B (Cores 27-261-10 to -26; 209-427.5 mbsf) is a dark gray, semilithified, uniformly layered claystone with a wide diversity of minor components. These intervals contain carbonate but again calcareous fossils are rare. Unit 4 (Cores 27-261-27 to $-33 ; 427.5-532.5 \mathrm{mbsf}$ ) is a brown semilithified claystone, normally devoid of calcareous fossils but with intermittent calcareous beds. The Cretaceous part occurs above 27-261-31-4.

No planktonic foraminifers were recorded from the Cretaceous section at Site 261, and calcareous benthic foraminifers are restricted to a few specimens at the base of the section. Agglutinated forms can be divided into a series of assemblages. Faunas from Cores 27-261-5 and -6 are characterized by Praecystammina globigerinaeformis Krasheninnikov accompanied by other multilocular agglutinated forms. Cores 27-261-7 and -8 have Haplophragmium lueckei (Cushman and Hedberg) and other agglutinated multilocular forms. Diversity is high (40 species in the upper assemblages, and 20 in the lower), but abundance low. Krasheninnikov (1974a) provided reasons for regarding these as deep-sea facies, as they are very different from anything known on neighboring continents because of the depth of accumulation, and he assigned an age of Turonian-lower Campanian to these faunas. The age of the lower assemblage is not as clearly defined as that of the upper assemblage.

Cores $27-261-9$ to -28 contain very poor agglutinated foraminifer faunas that have not been studied. Cores 27-261-29 to -31 (and deeper but not summarized here) contained a diverse fauna of agglutinated forms, dominated by unilocular and bilocular species (Kuznetsova, 1974; Bartenstein, 1974). Very rare calcareous forms were recorded by Kuznetsova (1974), who used the fauna in Cores 27-261-30 and -31 to diagnose a Valanginian age.

Calcareous nannoplankton (Proto Decima, 1974; Bukry, 1974d) are lacking or contain no age-diagnostic forms above Core 27-261-28. From there to Sample 27-261-31-3, $10 \mathrm{~cm}$, floras are Neocomian (probably including Berriasian, Valanginian, and Hauterivian). Calcareous nannoplankton have been taken to give a definitive placement of the Jurassic/ Cretaceous boundary in this hole. This is in conflict with the view of Kuznetsova (1974), who suggested that Cretaceous foraminifers continue downhole to Core 27-261-35 and that Jurassic elements had been reworked into the Cretaceous.

Radiolaria are present in most Cretaceous samples, but only in Cores $27-261-12$ to -23 are there faunas that can be diagnosed as Aptian-Senonian (Renz, 1974). Palynology at Site 261 (Wiseman and Williams, 1974) has been restricted to the interval covered by Cores $27-261-14$ to -26 . Cores 27261-14 to -16 are taken, on the basis of dinoflagellates, to be upper Aptian or lower Albian in age. The deeper cores, to Core 27-261-26, are Aptian. The age diagnosis of the Upper Cretaceous section (Cores 27-261-5 to -8) is based on agglutinated foraminifers, the Aptian-lower Albian (Cores 27261-14 to -26) on dinoflagellates, and the Neocomian (Cores 27-261-28 to -31) on calcareous nannoplankton and agglutinated foraminifers.

Thus, age controls throughout the Cretaceous at Site 261 are based on different fossil groups at different levels, and this situation shows the value of using many fossil groups, particularly where carbonates are rare or lacking. Traditional planktonic groups are of minor use stratigraphically at this site. Deposition at Site 261 seems always to have been below the CCD with the possible exception of the lowest parts, which may have been formed in fairly shallow waters. Little information is available for making judgments on water temperature or CCD history.

Site 263, situated in the Cuvier Abyssal Plain, was drilled in $5048 \mathrm{~m}$ water depth and penetrated $623 \mathrm{~m}$ of Cretaceous sediment, the thickest known from the Indian Ocean basin. It did not reach basement because of technical reasons. The Cretaceous section, represented by Cores $27-263-5$ to -29 , was divided (Veevers, Heirtzler, et al., 1974) into three lithologic units. This section was subject to analysis for several microfossil groups, and there are conflicting results in some parts.

Unit 2 (Cores 27-263-5 to -7; 100-195 mbsf) consists of gray to black, stiff clay nannofossil ooze and variants. Calcareous nannoplankton are common throughout; nannofossil abundance (and thus carbonate content) increases up section. Unit 3 (Cores $27-263-8$ to -19 ; $195-470$ mbsf) is a black, semilithified, claystone with trace amounts of a variety of constituents, including calcareous nannoplankton. Unit 4 (Cores 27-263-20 to $-29 ; 470-746$ mbsf) includes olive black, semilithified, quartzose silty claystone. Bioturbation and shell fragments are characteristic.

Scheibnerova (1974) described in detail the benthic foraminifer fauna from Samples 27-263-5-CC to $-29-C C$. Two broad divisions can be made. From Sample 27-263-5-CC to -16-CC, the fauna is dominated by agglutinated forms, but calcareous species are noteworthy. Below Core 27-263-16 the calcareous content increases markedly, with a much higher content of Lenticulina spp. and various nodosariid genera. The abundance of multilocular agglutinated forms also increases, at the expense of the unilocular and bilocular forms. Scheibnerova used the faunas to propose that all sedimentation occurred in waters less than $100 \mathrm{~m}$ deep and that, despite the absence of the important lingulogavellinellid faunas used in zonations on continental Australia, the section can be taken as Aptian (perhaps lower Albian at the top, perhaps pre-Aptian at the base).

There are no reports of planktonic foraminifers in this section other than in Core 27-263-4, in which Cretaceous faunas including heterohelicids and guembelitriids are reworked into the Paleocene (or younger) together with Lower Cretaceous agglutinated and calcareous forms. The planktonic foraminifers may indicate an Upper Cretaceous source nearby or on the Australian margin (where it exists in the upper Winning Group equivalents and later sediments; Geological Survey of Western Australia, 1975). The groups mentioned 
evolved late in the Early Cretaceous and reached their maximum development in the Late Cretaceous.

Lower Cretaceous calcareous nannoplankton were reworked into Core 27-263-4 but are otherwise occasional and non-age-diagnostic in Cores 27-263-5 to -21. An Albian age (but not attributable to any zone) is indicated for this interval. Cores 27-263-22 to -29 belong to the Eiffellithus turriseiffelii Zone, and Proto Decima (1974) argued that the flora is not known from the pre-Albian. She suggested that the flora indicates a middle to upper Albian age. Section 27-263-28-2 contains a flora not older than the middle Albian. Deeper cores do not contain age-diagnostic forms.

Bukry (1974d) has a markedly different interpretation of the Lower Cretaceous sequence at this site. Proto Decima regarded Section 27-263-5-28 as belonging to the E. turriseiffelii Zone of middle to upper Albian age, but Bukry placed the floras from Samples 27-263-4-2, $128 \mathrm{~cm}$, to $-24-4,48 \mathrm{~cm}$, in the Aptian; that part down to Sample 27-263-13-2, $45 \mathrm{~cm}$, was placed in the Parhabdolithus angustatus Zone, two zones older than the E. turriseiffelii Zone. He tentatively placed Sample 27-263-26-3, $75 \mathrm{~cm}$, in an even older zone, the Barremian Micrantholithus noschultzi Zone. Bukry's results are more in keeping with the foraminifer-based interpretation by Scheibnerova. Radiolaria occur occasionally in Cores 27-263-4 to -18 , but preservation is poor and no interpretation beyond "Cretaceous" is possible.

Bolli (1974) studied the calcisphaerulids from this site and identified four species that he took as Aptian or older (at the base of Cores 27-263-12 and -17) to ?lower Albian at the top (Cores 27-263-3 to -6). Wiseman and Williams (1974) examined palynomorphs and regarded the section in Cores 27-263-5 to -18 as Aptian, and the lower section down to Core 27-263-29 as Barremian. A range of the upper section into the lower Albian was noted as possible. Some reworking of Jurassic material occurred.

Thus, Proto Decima, Bukry, Scheibnerova, and Wiseman and Williams presented views of progressively older age assignment. This conflict in views of experienced specialists working in with different fossil groups that have been studied thoroughly in different parts of the world, illustrates the need for more detailed comparative studies. Even basic age assignments are not readily achievable in the Lower Cretaceous of the Indian Ocean basin.

Oertli (1974) recorded two species of ostracods from the Cretaceous section, and Stevens (1974) recorded the belemnite cf. Parahibolites sp. indet. from Sample 27-263-26-2, 108 $\mathrm{cm}$, taking it to be upper Albian, again in conflict with earlier views. He also noted an indeterminate ammonite. Authors studying Site 263 made little attempt to interpret the paleotemperature and CCD history.

Site 264 is on the southern flank of the Naturaliste Plateau and is credited on Table 2 with $46.5 \mathrm{~m}$ of Cretaceous. In fact, only 1.7 $\mathrm{m}$ of Cretaceous sediment (Core 28-264-11-1, $100 \mathrm{~cm}$, to $-2,120$ $\mathrm{cm} ; 169-170.7 \mathrm{mbsf}$ ) was cored. The additional $\sim 45 \mathrm{~m}$ takes into account the section below the sediment, which is a basaltic conglomerate. There may have been other soft sediments not recovered. The Cretaceous clayey nannofossil chalk is incorporated within lithologic Unit 3, which also includes a thick middle Paleocene and lower Eocene section above the Cretaceous. Thus, there are probably at least two unconformities within the unit. The Cretaceous part includes divitrified volcanic glass and up to $98 \%$ carbonate. Internal deformation is regarded as sedimentary and not imposed by drilling.

Hayes, Frakes, et al. (1975) recorded the foraminifer fauna from the Cretaceous sequence without any detailed discussion. The information presented suggests that the benthic fauna is similar to that of the Santonian/Campanian chalk and calcilutites of Western Australia (Belford, 1960). Not enough data are available for definitive judgment on the planktonic foraminifers, but they occur in the Western Australian Santonian/Campanian, although they are listed as Cenomanian/ Campanian. The listing of Marginotruncana coronata and Globotruncana linneiana is consistent only with an upper Santonian-lower Campanian age, not the broader range indicated in Hayes, Frakes, et al. (1975).

Not enough data are presented to be sure of the planktonic foraminifer province allocation (Sliter, 1977), but the absence of Rugoglobigerina and the dominance of Hedbergella-Globigerinelloides and Heterohelix is a little puzzling. This structure suggests that the faunas are not Tethyan or Austral. They are consistent with a Transitional Province, but Rugoglobigerina would be expected, even if not abundant. Allocation to the Transitional Province is used here, recognizing that this indicates warmer conditions than farther north, which Sliter takes to be Transitional/Austral. Bukry (1975) was more precise in his assignment. $\mathrm{He}$ attributed the entire Cretaceous chalk sequence to the Gartnerargo obliquum Zone, which he saw as bridging the Santonian/Campanian boundary.

Site 738 on the Southern Kerguelen Plateau was the first ODP hole to penetrate a Cretaceous section (Barron, Larsen, et al., 1989) on the Kerguelen Plateau, and a very significant one. The sequence passed without stratigraphic break from the Paleocene into the Maestrichtian at Sample 119-738C20R-5, $90 \mathrm{~cm}$ (377.1 mbsf). The base of the Cretaceous sequence is at the basalt contact in Sample 119-738C-31R-3, $41 \mathrm{~cm}$ (479.7 mbsf). Cretaceous sediments are included in lithologic Units V (part only) and VI, which have a disconformable contact.

Unit V (Cores $119-738 \mathrm{C}-8 \mathrm{R}$ to $-24 \mathrm{R} ; 254.4-418.6 \mathrm{mbsf}$ ) is a white to light greenish gray chalk with chert nodules and fragments. This sequence contains the continuous transition over the Cretaceous/Tertiary boundary where the rock is well bedded and disrupted neither by bioturbation nor by drilling effects. Chert and bioturbation structures are common above and below the boundary. There seems to be very little lithological change across the Cretaceous/Tertiary boundary. Unit VI (Core 119-738C-25 to Sample 119-738C-31R, $41 \mathrm{~cm}$; 418.6-479.7 mbsf) is a light gray to light olive gray bioturbated limestone with minor clay and chert. The limestone is partially silicified and silicification increases downhole. Inoceramus is present in places.

The Cretaceous portion of Unit V (Samples 119-738C-20R-5, $90 \mathrm{~cm}$, to -24R-2-CC; $377.1-412 \mathrm{mbsf}$ ) is upper Maestrichtian in age, belonging to the Abathomphalus mayaroensis Zone, marked by the presence of the nominate species. The fauna is diverse, including several "ornate" globotruncanids, Hedbergella and Heterohelix spp., and Globotruncanella havanensis. The presence of Rugoglobigerina indicates that the fauna should be placed in Sliter's (1977) Transitional Faunal Province, as suggested by Huber (1991a). Many aspects seem to indicate warmer conditions, but complex heterohelicids are absent and Rugoglobigerina is present. The fauna may be placed toward the warmer Tethyan part of the Transitional Faunal Province. The preservation of Maestrichtian forms is marred by minor overgrowths.

The section below the upper Maestrichtian (Section 119. 738C-24R-3 to Sample 119-738C-31R-3, $41 \mathrm{~cm}$; 412-479.7 mbsf) is taken to be Santonian/Campanian because of the presence of Costellagerina bulbosa (Belford) and Marginotruncana sp. Other genera present include Globigerinelloides, Hedbergella, and Heterohelix, all consistent with an Austral to Transitional Faunal Province. Huber (1991b) does not mention Rugoglobigerina sensu stricto, the presence of which would be expected. Preservation is much poorer than in the 
overlying Maestrichtian, possibly related to diagenesis during the microfracturing, which is characteristic of the limestone. Below 119-738C-28R-CC nothing is identified to species level because of poor preservation. Heterohelicids and hedbergellids are common, and the age assignment to the Santonian/ Campanian is, therefore, tentative.

Calcareous nannoplankton provide the best means of biostratigraphic subdivision of the section (Thierstein, in press). The detailed breakdown is as follows:

1. Samples $119-738 \mathrm{C}-20 \mathrm{R}-5,93 \mathrm{~cm}$, to $-24 \mathrm{R}-1,24 \mathrm{~cm}$, upper Maestrichtian, Nephrolithus frequens Zone (NC23 of Roth, 1978);

2. Samples $119-738 \mathrm{C}-24 \mathrm{R}-2,64 \mathrm{~cm}$, to $-24 \mathrm{R}-3,89 \mathrm{~cm}$, Campanian/Maestrichtian, Ceratolithoides aculeus (upper) to Lithaphridites quadratus zones (NC19b-NC22 of Roth, 1978);

3. Samples 119-738C-24R-CC to -26R-CC, Campanian, Aspidolithus parca-Ceratolithoides aculeus (lower) Zone (NC18-19a);

4. Samples $119-738 \mathrm{C}-27 \mathrm{R}-2,22 \mathrm{~cm}$, to $-28 \mathrm{R}-4,25 \mathrm{~cm}$, upper Santonian, Micula concava Zone (NC 17);

5. Samples 119-738C-28R-CC to -29R-CC, lower Santonian, Broinsonia lacunosa Zone (NC 16);

6. Samples $119-738 \mathrm{C}-30 \mathrm{R}-1,103 \mathrm{~cm}$, to $-30 \mathrm{R}-\mathrm{CC}$, upper Turonian/Coniacian, Micula staurophora-Marthasterites furcatus Zone (NC13-15); and

7. Samples 119-738C-31R-1, $77 \mathrm{~cm}$, to $-31 \mathrm{R}-\mathrm{CC}$, lower Turonian, Gartnerago obliquum Zone (NC12).

Cretaceous Radiolaria of upper Campanian-Maestrichtian age (Amphipynda tylotus Zone) were identified in Samples 119-738C-23R-CC to -26R-CC. Below that depth, samples were barren of Radiolaria. The Cretaceous section seems to be barren of palynomorphs.

There has been significant Ocean Drilling Program in the Indian Ocean since the drilling of Leg 120, but the results are not yet available in any final form and have not been included here.

\section{CONCLUSIONS}

There has been considerable drilling activity into the Cretaceous of the Indian Ocean, but the total effort for the area is still low compared with equivalently large regions of the world's oceans. No comprehensive sections of the Cretaceous have been recovered as a result of this activity, and not enough data are yet available for thorough paleoenvironmental reconstruction of the region during this important interval, which marks the main period for the origin and growth of this ocean basin. There is still not enough information to develop a Cretaceous biostratigraphic zonal scheme. Only for the Campanian-Maestrichtian can the record be used to provide any regional synthesis. There needs to be a search for other sections representing earlier intervals within the Cretaceous. Much more activity is needed, including integration of what is known from offshore and onshore sections.

\section{REFERENCES}

Barron, J., Larsen, B., et al., 1989. Proc. ODP, Init. Repts., 119: College Station, TX (Ocean Drilling Program).

Bartenstein, H., 1974. Upper Jurassic-Lower Cretaceous primitive arenaceous foraminifers from DSDP Sites 259, and 261, eastern Indian Ocean. In Veevers, J. J., Heirtzler, J. R., et al., Init. Repts. DSDP, 27: Washington (U.S. Govt. Printing Office), 683-695.

Bassias, Y., Davies, H., Leclaire, L., and Weis, D., 1987. Basaltic basement and sedimentary rocks from the southern sector of the Kerguelen-Heard Plateau: new data and their Meso-Cenozoic paleogeographic and geodynamic implications. Bull. Mus. Natl. Hist. Nat. Sect. C, 4:367-403.
Belford, D. J., 1960. Upper Cretaceous foraminifera from the Toolonga Calcilutite and Gingin Chalk, Western Australia. Bull. Bur. Miner. Resour., Geol. Geophys Aust., 57:1-198.

Bolli, H. M., 1974. Jurassic and Cretaceous Calcisphaerulidae from DSDP Leg 27, eastern Indian Ocean. In Veevers, J. J., Heirtzler, J. R., et al., Init. Repts. DSDP, 27: Washington (U.S. Govt. Printing Office), 843-907.

Bukry, D., 1974a. Coccolith and silicoflagellate stratigraphy, eastern Indian Ocean, Deep Sea Drilling Project, Leg 22. In von der Borch, C. C., Sclater, J. G., et al., Init. Repts. DSDP, 22: Washington (U.S. Govt. Printing Office), 601-607.

1974b. Coccolith stratigraphy, offshore Western Australia, Deep Sea Drilling Project, Leg 27. In Veevers, J. J., Heirtzler, J. R., et al., Init. Repts. DSDP, 27: Washington (U.S. Govt. Printing Office), 623-630.

1974c. Cretaceous and Paleogene coccolith stratigraphy, Deep Sea Drilling Project, Leg 26. In Davies, T. A., Luyendyk, B. P., et al, Init. Repts. DSDP, 26: Washington (U.S. Govt. Printing Office), 669-673.

1974d. Phytoplankton stratigraphy offshore East Africa, DSDP Leg 25. In Simpson, E.S.W., Schlich, R., et al., Init. Repts. DSDP, 25: Washington (U.S. Govt. Printing Office), 635-646.

1975. Coccolith and silicoflagellate stratigraphy near Antarctica, Deep Sea Drilling Project, Leg 28. In Hayes, D. E., Frakes, L. A., et al., Init. Repts. DSDP, 28: Washington (U.S. Govt. Printing Office), 709-723.

Burckle, L. H., Saito, T., and Ewing, M., 1967. A Cretaceous (Turonian) core from the Naturaliste Plateau, southeast Indian Ocean. Deep-Sea Res. Oceanogr. Abstr., 14:421-426.

Davies, T. A., Luyendyk, B. P., et al., 1974. Init. Repts. DSDP, 26: Washington (U.S. Govt. Printing Office).

Fisher, R. L., Bunce, E. T., et al., 1974. Init. Repts. DSDP, 24: Washington (U.S. Govt. Printing Office).

Gartner, S., Jr., 1974. Nannofossil biostratigraphy, Leg 22, Deep Sea Drilling Project. In von der Borch, C. C., Sclater, J. G., et al., Init. Repts. DSDP, 22: Washington (U.S. Govt. Printing Office), 577-599.

Gartner, S., Jr., Johnson, D. A., and McGowran, B., 1974. Paleontology synthesis of Deep Sea Drilling results from Leg 22 in the northeastern Indian Ocean. In von der Borch, C. C., Sclater, J. G., et al., Init. Repts DSDP, 22: Washington (U.S. Govt. Printing Office), 805-813.

Geological Survey of Western Australia, 1975. The geology of Western Australia. Mem. Geol. Surv. West. Aust., No. 2.

Hayes, D. E., Frakes, L. A. and others, 1975. Init. Repts. DSDP, 28: Washington (U.S. Govt. Printing Office).

Herb, R., 1974. Cretaceous planktonic foraminifera from the eastern Indian Ocean. In Davies, T. A., Luyendyk, B. P., et al., Init. Repts. DSDP, 26: Washington (U.S. Govt. Printing Office), 745-769.

Herb, R., and Scheibnerova, V., 1977. Synopsis of Cretaceous planktonic foraminifera from the Indian Ocean. In Heirtzler, J. R., Bolli, H. M., et al. (Eds.), Indian Ocean Geology and Biostratig. raphy. Am. Geophys. Union, 399-415.

Houtz, R. E., Hayes, D. E., and Markl, R. G., 1977. Kerguelen Plateau bathymetry, sediment distribution and crustal structure. Mar. Geol., 25:95-130.

Huber, B. T., 1991a. Planktonic foraminifer biostratigraphy of Campanian-Maestrichtian sediments from Sites 698 and 700, southern South Atlantic. In Ciesielski, P. F., Kristoffersen, Y., et al., Proc. ODP, Sci. Results, 114: College Station TX (Ocean Drilling Program), 281-297.

1991b. Maestrichtian planktonic foraminifer biostratigraphy and the Cretaceous/Tertiary boundary at Hole $738 \mathrm{C}$, Kerguelen Plateau (southern Indian Ocean). In Barron, J., Larsen, B., et al., Proc. ODP, Sci. Results, 119: College Station TX (Ocean Drilling Program), 451-466.

Johnson, B. D., Powell, C. McA., and Veevers, J. J., 1976. Spreading history of the eastern Indian Ocean and Greater India's northward flight from Antarctica and Australia. Geol. Soc. Am. Bull., 87:1560-1566.

Johnson, D. A., 1974. Radiolaria from the eastern Indian Ocean, DSDP Leg 22. In von der Borch, C. C., Sclater, J. G., et al., Init. Repts. DSDP., 22: Washington (U.S. Govt. Printing Office), 521-575. 
Krasheninnikov, V. A., 1974a. Upper Cretaceous benthonic agglutinated foraminifera, Leg 27 of the Deep Sea Drilling Project. In Veevers, J. J., Heirtzler, J. R., et al., Init. Repts. DSDP, 27: Washington (U.S. Govt. Printing Office), 631-661. 1974b. Cretaceous and Paleogene planktonic foraminifera, Leg 27 of the Deep Sea Drilling Project. In Veevers, J. J., Heirtzler, J. R., et al., Init. Repts. DSDP, 27: Washington (U.S. Govt. Printing Office), 663-671.

Kuznetsova, K. I., 1974. Distribution of benthonic foraminifera in Upper Jurassic and Lower Cretaceous deposits at Site 261, DSDP Leg 27, in the eastern Indian Ocean. In Veevers, J. J., Heirtzler, J. R., et al., Init. Repts. DSDP, 27: Washington (U.S. Govt. Printing Office), 673-681.

Larson, R. L., 1975. Late Jurassic sea-floor spreading in the eastern Indian Ocean. Geology, 3:69-71.

Le Pichon, X., and Heirtzler, J. R., 1968. Magnetic anomalies in the Indian Ocean and sea-floor spreading. J. Geophys. Res., 73:21012117.

McDougall, I., and Duncan, R. A., 1980. Linear volcanic chains recording plate motions? Tectonophysics, 63:275-295.

McGowran, B., 1974. Foraminifera. In von der Borch, C. C., Sclater, J. G., et al., Init. Repts. DSDP, 22: Washington (U.S. Govt. Printing Office), 609-627.

Müller, C., 1974. Calcareous nannoplankton, Leg 25 (western Indian Ocean). In Simpson, E.S.W., Schlich, R., et al., Init. Repts. DSDP, 25: Washington (U.S. Govt. Printing Office), 579-633.

Oertli, H. J., 1974. Lower Cretaceous and Jurassic ostracods from DSDP Leg 27: a preliminary account. In Veevers, J. J., Heirtzler, J. R., et al., Init. Repts. DSDP, 27: Washington (U.S. Govt. Printing Office), 947-965.

Perch-Nielsen, K., 1985. Mesozoic calcareous nannofossils. In Bolli, H., Saunders, J. B., and Perch-Nielsen, K. (Eds.), Plankton Stratigraphy: Cambridge (Cambridge Univ. Press), 329-426.

Pessagno, E. A., 1967. Upper Cretaceous planktonic foraminifera from the western Gulf Coastal Plain. Palaeontogr. Am., 5:245445.

Pessagno, E. A., and Michael, F. Y., 1974. Mesozoic foraminifera, Leg 22, Site 217. In von der Borch, C. C., Sclater, J. G., et al., Init. Repts. DSDP, 22: Washington (U.S. Govt. Printing Office), 629-634.

Pimm, A. C., 1974. Sedimentology and history of the Northeastern Indian Ocean from late Cretaceous to Recent. In von der Borch, C. C., Sclater, J. G., et al., Init. Repts. DSDP, 22: Washington (U.S. Govt. Printing Office), 717-803.

Proto Decima, F., 1974. Leg 27 calcareous nannoplankton. In Veevers, J. J., Heirtzler, J. R., et al., Init. Repts. DSDP, 27: Washington (U.S. Govt. Printing Office), 589-621.

Quilty, P. G., 1973. Cenomanian-Turonian and Neogene sediments from northeast of Kerguelen Ridge, Indian Ocean. J. Geol. Soc. Aust., 20:361-368.

1979. The Late Cretaceous-Tertiary section in Challenger No. 1 (Perth Basin): details and implications. Bull. Bur. Miner. Resour. Geol. Geophys. Aust., 192:109-135.

1984. Cretaceous foraminiferids from Exmouth Plateau and Kerguelen Ridge, Indian Ocean. Alcheringa, 8:225-241.

Renz, G. W., 1974. Radiolaria from Leg 27 of the Deep Sea Drilling Project. In Veevers, J. J., Heirtzler, J. R., et al., Init. Repts. DSDP, 27: Washington (U.S. Govt. Printing Office), 769-841.

Riedel, W. R., and Sanfilippo, A., 1974. Radiolaria from the southern Indian Ocean, DSDP Leg 26. In Davies, T. A., Luyendyk, B. P., et al., Init. Repts. DSDP, 26: Washington (U.S. Govt. Printing Office), 771-813.

Roth, P. H., 1974. Calcareous nannofossils from the northwestern Indian Ocean, Leg 24, Deep Sea Drilling Project. In Fisher, R. L., Bunce, E. T., et al., Init. Repts. DSDP, 24: Washington (U.S. Govt. Printing Office), 969-994.
1978. Cretaceous nannoplankton biostratigraphy and oceanography of the northwestern Atlantic Ocean. In Benson, W. E., Sheridan, R. E., et al., Init. Repts. DSDP, 44: Washington (U.S. Govt. Printing Office), 731-759.

Royer, J.-Y., and Sandwell, D. T., 1989. Evolution of the eastern Indian Ocean since the Late Cretaceous: constraints from Geosat altimetry. J. Geophys. Res., 94:13755-13782.

Scheibnerova, V., 1971. The Great Artesian Basin, Australia, a type area of the Austral Biogeoprovince of the Southern Hemisphere, equivalent to the Boreal Biogeoprovince of the Northern Hemisphere. In Farinacci, A. (Ed.), Proceedings of the Second International Conference on Planktonic Microfossils, Roma: Rome (Ed. Technoscienza), 1129-1138.

1974. Aptian-Albian benthonic foraminifera from DSDP Leg 27, Sites 259, 260 and 263, eastern Indian Ocean. In Veevers, J. J., Heirtzler, J. R., et al., Init. Repts. DSDP, 27: Washington (U.S. Govt. Printing Office), 697-742.

Schlich, R., 1982. The Indian Ocean: aseismic ridges, spreading centers, and oceanic basins. In Nairn, A.E.M., and Stehli, F. G. (Eds.), The Ocean Basins and Margins (Vol. 6): New York (Plenum), 51-147.

Sigal, J., 1974. Comments on Leg 25 sites in relation to the Cretaceous and Paleogene stratigraphy in the eastern and southeastern African and Madagascar regional setting. In Simpson, E.S.W., Schlich, R., et al., Init. Repts. DSDP, 25: Washington (U.S. Govt. Printing Office), 687-723.

Simpson, E.S.W., Schlich, R., et al., 1974. Init. Repts. DSDP, 25 : Washington (U.S. Govt. Printing Office).

Sissingh, W., 1977. Biostratigraphy of Cretaceous calcareous nannoplankton. Geol. Mijnbouw, 57:37-65.

Sliter, W. V., 1972. Cretaceous foraminifers-depth habitats and their origin. Nature, 239:514-515.

1977. Cretaceous foraminifers from the southwestern Atlantic Ocean, Leg 36, Deep Sea Drilling Project. In Barker, P., Dalziel, I.W.D., et al., Init. Repts. DSDP, 36: Washington (U.S. Govt. Printing Office), 519-574.

Speden, I. G., 1974. Cretaceous Bivalvia from cores, Leg 27. In Veevers, J. J., Heirtzler, J. R., et al., Init. Repts. DSDP, 27: Washington (U.S. Govt. Printing Office), 977-981.

Stevens, G. R., 1974. Leg 27 Cephalopoda. In Veevers, J. J., Heirtzler, J. R., et al., Init. Repts. DSDP, 27: Washington (U.S. Govt. Printing Office), 983-986.

Thierstein, H. R., 1974. Calcareous nannoplankton, Leg 26, Deep Sea Drilling Project. In Davies, T. A., Luyendyk, B. P., et al., Init. Repts. DSDP, 26: Washington (U.S. Govt. Printing Office), 619-667.

Veevers, J. J., 1977. Paleobathymetry of the crest of spreading ridges related to the age of ocean basins. Earth Planet. Sci. Lett., $34: 100-106$.

1984. Phanerozoic Earth History of Australia: Oxford (Clarendon Press).

Veevers, J. J., Heirtzler, J. R., et al., 1974. Init. Repts. DSDP, 27: Washington (U.S. Govt. Printing Office).

von der Borch, C. C., Sclater, J. G., et al., 1974. Init. Repts. DSDP, 22: Washington (U.S. Govt. Printing Office).

Wiseman, J. F., and Williams, A. J., 1974. Palynological investigation of samples from Sites 259, 261, and 263, Leg 27 Deep Sea Drilling Project. In Veevers, J. J., Heirtzler, J. R., et al., Init. Repts. DSDP, 27: Washington (U.S. Govt. Printing Office), 915-924.

Date of initial receipt: 24 October 1990

Date of acceptance: 13 November 1990

Ms 120B-204 